\title{
KAJIAN STRUKTUR DRAMATIK DAN ALUR CERITA FILM TOBA DREAMS KARYA BENNY SETIAWAN
}

\author{
Sri Wahyuni \\ Program Studi Televisi dan Film \\ Fakultas Seni dan Desain Universitas Potensi Utama \\ sriwahyuni2909@gmail.com
}

\begin{abstract}
ABSTRAK
Tulisan ini bermaksud untuk menjelaskan struktur dramatik dan bentuk alur cerita yang terdapat dalam film Toba Dreams. Penelitian ini menggunakan penelitian kualitatif deskriptif yang digunakan untuk mengungkap plot/alur cerita yang ada pada film Toba Dreams. Film Toba Dreams mengandung unsur naratif yang membentuk rangkaian peristiwa yang saling terkait satu sama lain dan terhubung oleh sebab akibat (kausalitas) yang terjadi dalam ruang dan waktu. Tema yang terkandung dalam film Toba Dreams yaitu budaya, agama dan cinta. Perasaan cinta yang sangat luar biasa dimiliki seorang ayah yaitu Sersan Mayor Tebe (Mathias Muchus) terhadap anak-anaknya karena perasaan tersebut Sersan Tebe mendidik anak-anaknya layaknya pasukan tempur. Pertentangan terjadi dalam isi cerita film Toba Dreams yang menyebabkan adanya konflik dari awal hingga akhir. Maka pendekatan Struktur Dramatik (Exposition, Inciting-action, Crisis, Climax, Resolution dan Conlusion) digunakan agar dapat mengetahui perkembangan alur cerita, karakter tokoh, klimaks dari permasalahan hingga tahap akhir cerita sebagai penutur alur dramatik.
\end{abstract}

Kata Kunci: Struktur Dramatik, Film Toba Dreams, Plot/Alur

\begin{abstract}
This paper aims to describe the dramatic structure and form of the story line contained in the movie Toba Dreams. This study uses descriptive qualitative research to reveal the plot/storyline that existed in the movie Toba Dreams. The Toba Dreams film contains a narrative element that forms a series of events and interconnected with each other and is related by causality (causality) that occurs in space and time. The themes contained in the Toba Dreams film is culture, religion and love. A great feeling of love is owned by a father, Sergeant Major Tebe (Mathias Muchus) against his children because of the feeling that Sergeant Tebe educates his children like combat troops. Controversy occurs in the contents of the Toba Dreams movie story that causes a conflict from beginning to end. So the approach of Dramatic Structure (Exposition, Inciting-action, Crisis, Climax, Resolution and Conlusion) is used to know the development of the story, character, climax of the problem and the final stage which is the conclusion of the story content to tell the dramatic flow.
\end{abstract}

Keywords: Dramatic Structure, Toba Dreams Movie, Plot

\section{PENDAHULUAN}

Sejak awal abad 19 hingga saat ini, film telah menjadi bagian dari hidup manusia. Pratista mengungkapkan bahwa film merupakan kebudayaan yang diciptakan manusia dan memiliki dampak besar bagi masyarakat. Film juga dapat diartikan sebagai salah satu bentuk seni, sumber hiburan dan alat yang ampuh untuk mendidik serta mengindoktrinasi 
para penontonnya. Penonton dapat berperan aktif melalui pengalaman mental dan budaya yang telah dimiliki baik secara sadar maupun tidak sadar mampu memahami sebuah film. (Pratista, 2008:3). Toba Dreams merupakan film Indonesia yang diadaptasi dari sebuah novel yang berjudul Toba Dreams karangan T.B. Silalahi. Novel Toba dreams diangkat menjadi sebuah karya audio visual (film) dengan disutradarai dan penulis naskah yaitu Benny Setiawan. Tema yang terkandung dalam film Toba Dreams yaitu Budaya, Agama dan Cinta. Perasaan cinta yang sangat luar biasa dimiliki seorang ayah yaitu Sersan Mayor Tebe (Mathias Muchus) terhadap anak-anaknya karena perasaan tersebut Sersan Tebe mendidik anak-anaknya layaknya pasukan tempur. Sersan Tebe berharap anakanaknya menjadi seperti dirinya, akan tetapi putra sulungnya yaitu Ronggur (Vino G Bastian) justru menjadi anak yang keras kepala serta bertolak belakang dari Sersan Tebe yang menyebabkan konflik selalu terjadi. Ronggur memilih menjalani kehidupannya sendiri dan tidak mendengarkan setiap nasehat yang diberikan oleh ayahnya.

Suatu hari Ronggur mencintai seorang wanita berketurunan Jawa dan beragama Islam yaitu Andini (Marsha Timothy). Ronggur dan Andini menjalin hubungan sepasang kekasih namun kedua orang tua Andini tidak menyetujuinya karena perbedaan agama keduanya serta Ronggur yang tidak memiliki pekerjaan dan pendidikan yang setara dengan Andini. Ayah Ronggur yaitu Sersan Mayor Tebe yang telah pensiun membawa istri dan anakanaknya termasuk Ronggur kembali kekampungnya yaitu Danau Toba. Namun, hal itu ditolak oleh Ronggur meskipun Ronggur sempat ikut ke Danau Toba akan tetapi Ronggur kembali lagi ke Jakarta untuk menemui kekasihnya Andini. Konflik kembali terjadi terhadap Ronggur dan Andini karena Andini telah dijodohkan oleh keluarganya dengan pria berpendidikan baik. Konflik tersebut merupakan konflik berganda. Konflik berganda (Multi Plot) yang terdapat dalam suatu struktur dramatik film dapat diartikan sebagai perangkat dalam membangun hubungan antar alur cerita kemudian saling mengembangkan satu dengan yang lainnya sehingga dapat menimbulkan rasa keingintahuan dan penasaran dari penonton (Pratista, 2008:36). Keterkaitan alur cerita memunculkan akibat aksi, tindakan dari pelaku cerita yang memotivasi terjadinya kesatuan peristiwa pada film Toba Dreams. Menurut Haig P. Manoogian alur cerita ( $p l o t)$ merupakan penggambaran dari sebuah cerita film yang terdiri dari rentetan kejadian bermotivasi dan memiliki hubungan sebab akibat. Struktur tersebut telah menjadi petunjuk yang terdapat dalam kejadiankejadian dari plot tersebut (Paransi, 2005: 8).

Rangkaian peristiwa atau konflik yang terjadi dalam alur cerita terdapat dalam struktur dramatik yang menyangkut perkembangan cerita dari awal hingga akhir. Menurut Brechtian (Bertolt Brecht) dalam Rickrik El Saptaria bahwa struktur dramatik memiliki tujuh tahapan yaitu Exposition, pada tahap ini merupakan awal dalam sebuah cerita yang telah memberi penjelasan mengenai tokoh-tokoh, masalah, tempat dan waktu ketika cerita berlangsung; Inciting-action yakni sebuah peristiwa dimana seorang tokoh mulai memberikan adegan-adegan yang dapat membangun penanjakan aksi menuju sebuah konflik; Conflication dapat diartikan sebagai upaya salah seorang tokoh dalam mencapai tujuan tertentu, meskipun aksi tersebut masih dibayang-bayangi oleh ketidakpastian; Crisis yakni perkembangan yang terjadi karena adanya suatu tindakan dalam alur cerita kemudian bergerak maju menuju klimaks. Climax dibangun oleh peristiwa-peristiwa konflikasi, Biasanya pada tahapan ini para tokoh yang berlawanan saling berhadapan dalam situasi puncak konflik/pertentangan; Resolution, pada tahapan ini para tokoh di pertemukan dengan semua masalah-masalah yang terjadi dengan tujuan untuk mendapatkan solusi atau pemecahan masalah tersebut; Conlusion, pada tahapan ini merupakan ending dalam sebuah cerita atau para tokoh mendapat kepastian apakah sad 
ending atau happy ending atau dapat berupa pesan-pesan moral dari peristiwa-peristiwa yang terjadi (Rickrik El Saptaria, 2006:27).

Sedangkan Alur cerita/plot menurut Rickrik El Saptaria merupakan rentetan peristiwa yang terjadi kemudian dikaitkan dengan hokum sebab akibat. Plot sendiri dibagi dalam beberapa jenis yaitu Simple plot/Single plot yakni satu alur cerita memiliki satu konflik yang bergerak maju dari awal cerita hingga akhir, Multi plot/plot berganda yakni memiliki satu alur cerita utama dengan beberapa sub plot yang memiliki hubungan atau keterkaitan satu dengan yang lainnya, dan episodic plot merupakan alur terpusat atau konsentrik dimana cerita yang terdapat dalam sebuah peristiwa berdiri secara bagian perbagian atau dapat diartikan secara mandiri dimana setiap episode memiliki alur ceritanya sendiri kemudian pada akhir cerita semua tokoh akan terlibat dan akhirnya menyatu (Rickrik El Saptaria, 2006:21).

Penelitian ini menggunakan metode deskriptif analistik, yaitu data-data yang telah diperoleh akan dilakukan pendeskripsian sebagai upaya dalam mengkaji sebuah film yaitu Toba Dreams berdasarkan pisau analisis dalam hal ini struktur dramatik dan alur ceritanya. Analisis deskriptif bertujuan agar masalah yang dianalisa dapat diinterpretasikan secara jelas dengan langkah-langkah operasional penelitian, hal ini bertujuan agar mendapatkan hasil sesuai dengan rumusan serta tujuan dan manfaatnya.

\section{Studi Literatur}

Penelusuran beberapa referensi yang terkait dengan penelitian yang dilakukan adalah :

Tulisan Fajar Aji (2013) dalam tesisnya yang berjudul "Studi Estetika Film Nagabonar Jadi 2 Karya Deddy Mizwar". Tesis ini menjelaskan keberadaan film Nagabonar Jadi 2 pada tahun 2007, Struktur Dramatik dan Estetika yang dikandungnya. Penelitian ini pada dasarnya menggunakan penelititan kualitatif dengan menggunakan pendekatan estetika untuk memberikan kontribusi keindahan, cita rasa dan pengalaman estetis. Penelitian ini tidak hanya membahas mengenai estetika sebagai pendekatannya namun juga mengungkap struktur dramatik nya sebagai penataan kembali cerita secara keseluruhan menjadi bagianbagian yang mampu menginformasikan karakter protagonis, antagonis, dan tritagonis yang memainkan perannya, masalah dan tujuan apa yang ingin dicapai. Aspek ruang dan waktu yang digunakan dan berkembang menjadi rangkaian cerita secara keseluruhan. Unsur unsur atau elemen-elemen dasar pembentuk yang ada (naratif dan sinematik) saling berhubungan satu sama lain dalam satu kesatuan sistem yang terstruktur, sehingga menghasilkan sebuah tayangan (audiovisual) yang mampu memberikan kontribusi keindahan, cita rasa, dan pengalaman estetis yang membuat penonton ikut merasakan suasana lucu, sedih, haru, gembira, serta dapat menyerap maksud dan tujuan yang ingin disampaikan. Persamaannya dengan penelitian ini sama-sama menggunakan pendekatan struktur dramatik sedangkan penelitian yang akan dilakukan mengurai struktur dramatik serta bentuk alur cerita film Toba Dreams Karya Benny Setiawan sebagai Objek penelitiannya.

Selanjutnya Yogian Hutagama (2014) dalam tesisnya yang berjudul "Struktur Dramatik Naskah Miniseri Sengsara Membawa Nikmat Karya Asrul Sani” Penelitian ini memiliki tujuan untuk mengungkap struktur dramatik yang terdapat dalam Naskah Miniseri Sengsara Membawa Nikmat melalui pendekatan struktural dan metode analisis deskriptif yang digunakan sebagai pisau analisis penelitian ini. Pendekatan structural sendiri digunakan agar dapat mengetahui perkembangan cerita, tokoh/penokohan, klimaks dan tahap akhir dari cerita yang menjadi sebuah kesimpulan. Hasil yang didapat dalam penelitian ini yaitu cerita dalam Naskah Miniseri Sengsara Membawa Nikmat menyampaikan pesan dan maknanya melalui nilai moral, ajaran religi dan seni budaya 
yang memiliki sifat edukatif bagi penontonnya. Sifat kebudayaan dapat dilihat pada karakter para tokohnya.

Tulisan ini memiliki persamaan dengan penelitian tersebut. Persamaan tersebut terletak pada metode yang digunakan yaitu mengkaji atau menganalisis sebuah film dengan kajian struktur dramatik. Namun, tulisan ini berbeda dengan penelitian yang telah ada yaitu terletak pada objek film yang digunakan, yang mana penelitian diatas mengkaji pada sebuah film "Sengsara Membawa Nikmat" sedangkan penelitian yang akan dilakukan ini adalah kajian Struktur dramatik dan bentuk alur cerita dalam film Toba Dreams Karya Benny Setiawan.

\section{PEMBAHASAN}

Film umumnya dibangun oleh dua aspek pembentuk film yaitu unsur naratif dan unsur sinematik. Dua unsur tersebut saling berkaitan, berinterkasi dan berkesinambungan satu sama lain sehingga dapat membentuk sebuah film. Dalam film fiksi unsur naratif seperti penggerak dari sebuah cerita sedangkan sinematik merupakan teknis pembentuk film. Seperti halnya, Cerita yang terdapat pada sebuah film memuat unsur naratif dalam bentuk rentetan peristiwa yang memiliki hubungan satu sama lain serta berkaitan dengan logika sebab akibat (kausalitas) yang terjadi dalam ruang dan waktu. Cerita dalam Film Toba Dreams memunculkan akibat aksi, tindakan dari pelaku cerita yang memotivasi terjadinya kesatuan peristiwa yang memuat unsur-unsur plot. plot Menurut Haig P. Manoogian Alur cerita (plot) yaitu penjelasan dari cerita sebuah film yang terdiri dari rangkaian kejadian bermotivasi serta berhubungan secara sebab akibat. Sedangkan Plot menurut Paransi rangkaian peristiwa yang disajikan dalam bentuk audio visual pada film (Pratista, 2008: 33).

Plot sebagian besar dituturkan dalam pola linier dimana urutan waktu berjalan sesuai urutan aksi peristiwa tanpa adanya interupsi waktu yang signifikan. Elemen-elemen naratif yang membantu jalannya sebuah alur cerita adalah pelaku cerita yang menjadi penggerak utama dalam menjalankan sebuah alur cerita seperti tokoh protagonis (utama/jagoan) dan antagonis (pendukung/musuh/rival). Permasalahan/konflik sendiri yang menjadi penghalang tokoh protagonis dalam mencapai tujuannya. Tujuan yang ingin dicapai oleh pelaku sebagai penggerak cerita dapat berupa fisik yaitu dapat mengalahkan musuh atau dapat berupa non fisik seperti pada akhir cerita mendapat kebahagiaan dan sebagainya (Pratista, 2008: 44).

Dengan demikian, pelaku cerita sebagai penggerak cerita yang menjalankan alur naratif sejak awal hingga akhir cerita. Tokoh utama dapat diistilahkan sebagai pihak protagonis sedangkan karakter pendukung dapat berada dipihak protagonis atau antagonis sebagai pemicu adanya konflik, dalam hal ini tokoh utamanya adalah Sersan Mayor Tebe yang diperankan oleh Mathias Muchus dan pihak Antagonis Ronggur yang diperankan Vino G Bastian. Sersan Mayor Tebe yang sangat mencintai anak-anaknya membuatnya mendidik keras anak-anaknya seperti pasukan tempur mengikuti keinginannya berharap anakanaknya dapat menjadi seperti yang diharapkankan. Namun, hal tersebut justru berbalik, putra sulungnya yang bernama Ronggur memiliki sifat yang sama dengan ayahnya yang keras. Ronggur menjadi seorang pemberontak didalam keluarganya sehingga hal tersebut menjadi persoaalan atau konflik yang terjadi anatara ayah dan anak.

Pertentangan ini yang menjadi esensi drama yang disebut dengan istilah konflik (Mark, 1985: 41). Konflik merupakan dasar drama seperti pertentangan yang dialami seorang tokoh sebagai respon atas timbulnya kekuatan-kekuatan dramatis (Dietrich, 1953: 78). 
Film Toba Dreams sendiri bergenre drama, yang pada dasarnya drama berarti pencerminan dalam kehidupan manusia di masyarakat. Dalam cerita kehidupan masyarakat tentunya manusia memiliki permasalahan-permasalahan ataupun pertentangan-pertentangan baik fisik maupun psikis dalam hal ini adalah Ronggur yang ingin menentang keinginanan ayahnya. Menurut Mark drama yang baik biasanya memiliki konflik yang selalu keterkaitan dengan tema dan alur, maksudnya seperti tema terbangun melalui alur yang kuat serta dapat menarik sebuah perhatian karena adanya susunan jalinan konflik-konflik yang matang dan terarah serta tersebar secara merata dalam setiap alur tersebut (Mark, 1985: 85).

Dengan demikian konflik yang terdapat dalam film Toba Dreams merupakan suatu persoalan yang bergerak maju pada satu klimaks atau bagian alur cerita yang telah menggambarkan permasalahan atau pertentangan yang di alami para tokoh, maupun permasalahan atau pertentangan tersebut terjadi di luar tokoh utama, hal ini merupakan penggambaran yang diberikan oleh seorang sutradara sebagai upaya menarik penonton untuk menduga-duga perkembangan cerita selanjutnya. Struktur dramatik yang memuat alur/plot pada film Toba Dreams dari awal hingga akhir. Struktur Dramatik yang terdapat dalam film Toba Dreams dapat diuraikan sebagai berikut:

\section{Exposition}

Pada tahap ini menggambarkan bagian awal cerita film Toba Dreams yang telah memberikan penggambaran, uraian dan keterangan tentang tokoh-tokoh cerita, masalahmasalah yang sedang dihadapi serta tempat dan waktu ketika cerita berlangasung. Penggambaran tersebut membentuk pola alur cerita pada film Toba dreams dan memberikan informasi kepada penonton mengenai cerita yang akan disampaikan. Sutradara memberikan gambaran permasalahan-permasalahan atau konflik yang sedang terjadi pada tokoh dalam tahap Exposition sehingga penonton dapat memahami jalan cerita yang disampaikan pada film Toba Dreams.

Tahap Exposition pada film Toba Dreams dimulai dengan pengenalan karakter Sersan Mayor Tebe sebagai pasukan Tentara Angkatan Darat (TNI - AD) yang baru pensiun dari tugasnya dan berniat ingin membawa keluarganya pindah ke Desa yaitu di Toba. Gambaran tersebut dapat dilihat pada scene 4 sebagai berikut:

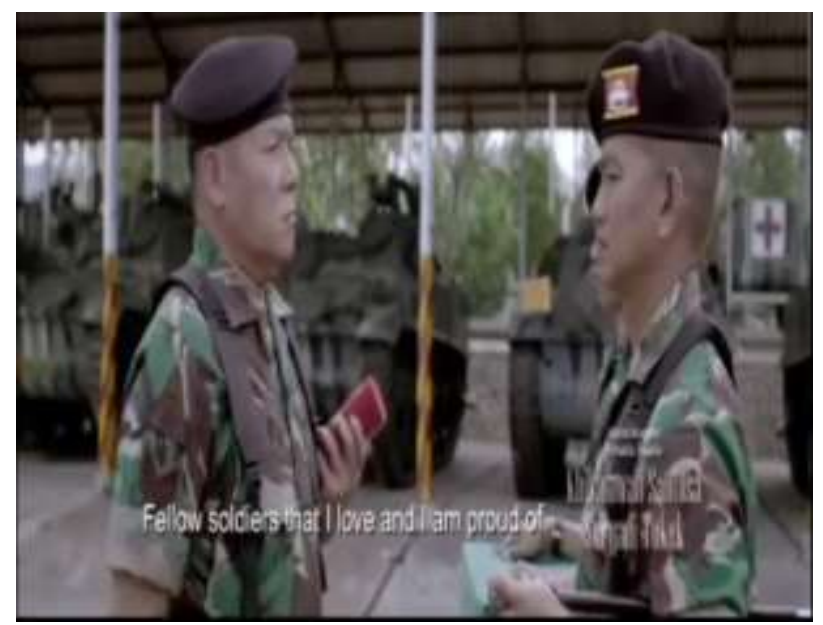

Gambar 1. Sersan Mayor Tebe mendapat piagam penghargaan (Pensiun)

Pada gambar 1 terlihat Sersan Mayor Tebe mendapatkan penghargaan pada saat pensiun. Hal ini menggambarkan karakter Sersan Mayor Tebe sebagai prajurit yang berprestasi. Namun, disisi lain pada saat Sersan Mayor Tebe mendapatkan penghargaan dan memberikan sambutan terakhirnya, justru karakter Ronggur juga diperkenalkan 
dengan cuplikan-cuplikan gambar yang menunjukkan perbandingan karakter ayah dan anak tersebut.

\section{Inciting-Action}

Tahap Inciting-Action mulai menjelaskan sebuah peristiwa dimana seorang tokoh mulai memberikan adegan-adegan yang dapat membangun kenaikan aksi menuju sebuah konflik. Pada tahapan ini sudah mulai dijelaskan laku karakter yang menyebabkan mulai terjadi perumitan sebuah cerita. Penanjakan aksi terlihat Sersan Mayor Tebe yang telah pensiun dari pekerjaannya memilih ingin pulang ke kampungnya membawa serta keluarganya. Ronggur sebagai putra sulung Sersan Mayor Tebe menentang keinginan ayahnya untuk pindah kekampung halaman ayahnya di Toba. Pada scene 7 terlihat penanjakan aksi yang dilakukan Ronggur yang menajadikan sebuah konflik dalam cerita. Scene 7 digambarkan sebagai berikut:

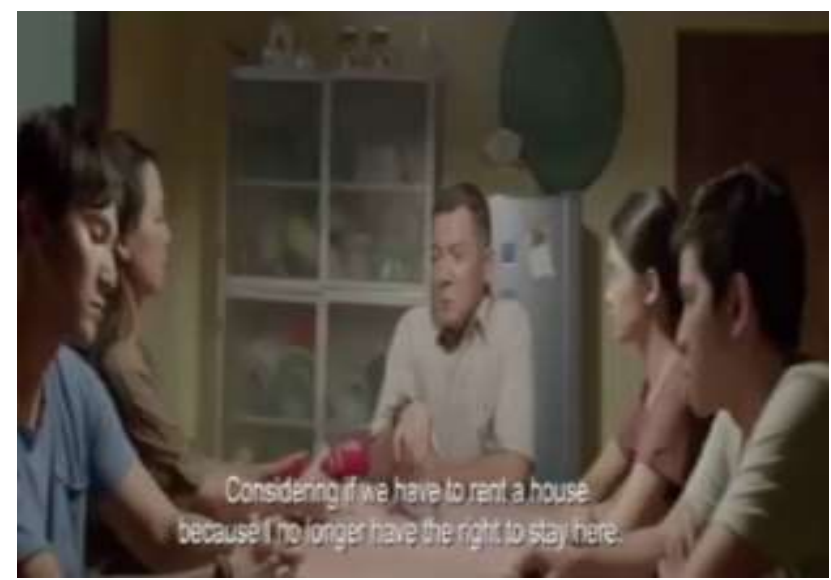

Gambar 2. Sersan Mayor Tebe dan Keluarga Membicarakan Perpindahan Mereka ke Desa

Gambar 2 menjelaskan bahwa Sersan Mayor Tebe mengajak keluarganya untuk pindah ke kampung halamannya yaitu di Toba Samosir. Tetapi keinginannya di tentang oleh Ronggur sebagai putra sulungnya. Ronggur membantah perkataan ayahnya, namun Sersan Mayor Tebe tetap kepada pendiriannya yaitu pindah ke desa meskipun Ronggur menentangnya. Pada scene inilah terjadi penaikan aksi yang dimulai dari keluarga.

\section{Conflication}

Pada tahapan ini merupakan upaya salah seorang tokoh dalam mencapai tujuan tertentu, meskipun aksi tersebut masih dibayang-bayangi oleh ketidakpastian. Disini sudah mulai dijelaskan peristiwa yang dialami karakter -karakter tertentu dalam mengatasi konflik namun tidak mudah untuk mengatasinya sehingga menimbulkan rasa frustasi, amukan, kekecewaan, ketakutan, kemarahan. Konflik ini terus mengalami penanjakan danb semakin rumit sehingga membuat karakter-karakter tersebut merasa semakin tertekan serta terus berusaha untuk mencari solusi dari konflik tersebut.

Tahap Conflication ini terjadi kerumitan antara hubungan Sersan Mayor Tebe dan Ronggur yang sama-sama memiliki sifat yang keras. Ronggur yang ikut ayahnya pindah ke kampung merasa tidak senang dan melarikan diri ke kota Jakarta untuk bertemu dengan kekasihnya Andini sekaligus mencari pekerjaan. Namun, kekecewaan dirasakan Ronggur karena melihat Andini telah dijodohkan dengan pria lain oleh keluarganya. Hubungan Andini dan Ronggur tidak disetujui dikarenakan perbedaan Agama diantara keduanya dan perbedaan status sosial. Hal ini terlihat pada scene 27 sebagai berikut: 


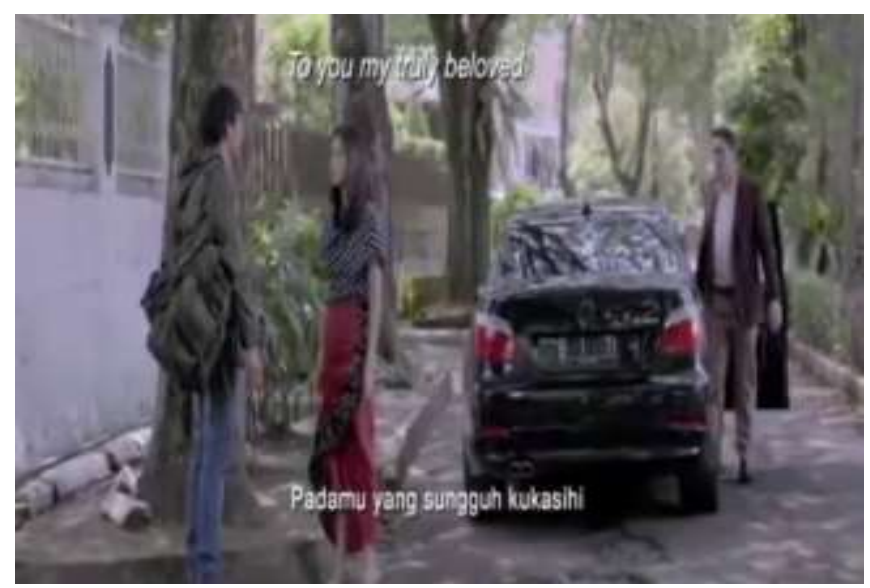

Gambar 3. Ronggur menemui Andini di Jakarta

Gambar 3 menjelaskan Ronggur yang menemui Andini dengan sangat bahagia setelah melarikan diri dari keluarganya di kampung. Tetapi, justru Andini telah bersama lelaki lain yang membuat Ronggur merasa kecewa dengan Andini. Ronggur yang kecewa kemudian pergi meninggalkan Andini dan tunangannya.

\section{Crisis}

Tahapan Crisis dilakukan karena adanya perkembangan dalam suatu peristiwa atau suatu tindakan dalam alur cerita menuju klimaks. Dalam tahapan ini, Ronggur merasa prustasi dengan masalah yang dihadapinya. Permasalahan tidak hanya terhadap Keluarganya melainnya juga dengan kekasihnya Andini. Disisi lain, Ronggur Yang berprofesi sebagai supir taksi terjebak dengan sekumpulan mafia Narkoba. Hal ini digambarkan pada scene 42 Sebagai berikut:

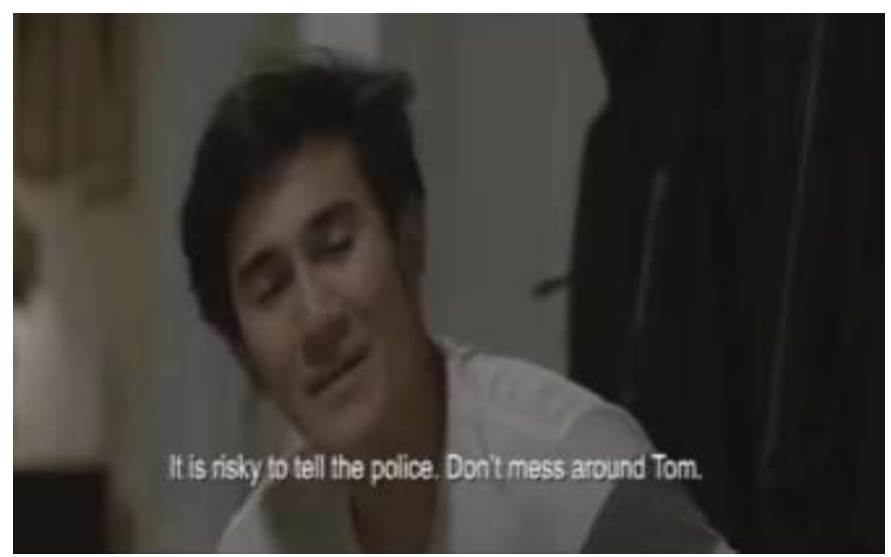

Gambar 4. Ronggur Prustasi dan menceritakan masalahnya terhadap Tomi

Crisis terjadi pada Ronggur yang telah mendapatkan pekerjaan sebagai sopir taksi, tetapi dijebak dengan sekelompok mafia narkoba. Mafia narkoba tersebut mengancam Ronggur jika tidak mengikuti kemauan mereka. Pada scene ini Ronggur merasa sangat tertekan, hal ini ditandai dengan Ronggur menceritakan permasalahannya terhadap Tomi (temannya).

\section{Climax}

Tahapan Climax yang menjadi bagian dari plot/alur cerita dalam menjelaskan peristiwa dramatik yang mempertemukan semua masalah-masalah yang terjadi pada para tokoh dengan maksud untuk mendapatkan solusi atau pemecahan dari permasalahan 
tersebut. Pada tahapan ini semua permasalahan akan terungkap dan mendapatkan penggambaran baik melalui laku karakter maupun lewat dialog yang disampaikan oleh peran. Sehingga penonton dapat mengerti dengan permasalahan yang dihadapi tokoh melalui laku karakter ataupun dialog yang disampaikan.

Film Toba Dreams menguraikan permasalahan melalui tokoh Ronggur yang telah terjebak dengan perumitan masalah yang besar. Mulai dari permasalahannya dengan Sersan Mayor Tebe yaitu ayahnya, permasalahannya dengan keluarga Andini yang melarangnya untuk tidak berhubungan dengan Andini hingga terjebaknya Ronggur dengan mafia-mafia narkoba. Ronggur yang tidak memiliki pilihan bergabung dengan mafia-mafia narkoba tersebut. Keputusan tersebut dipilih karena perkataan orang tua Andini yang menyudutkan Ronggur sebagai kekasih Andini. Peristiwa-peristiwa tersebut dapat dilihat pada scene 44 sebagai berikut:

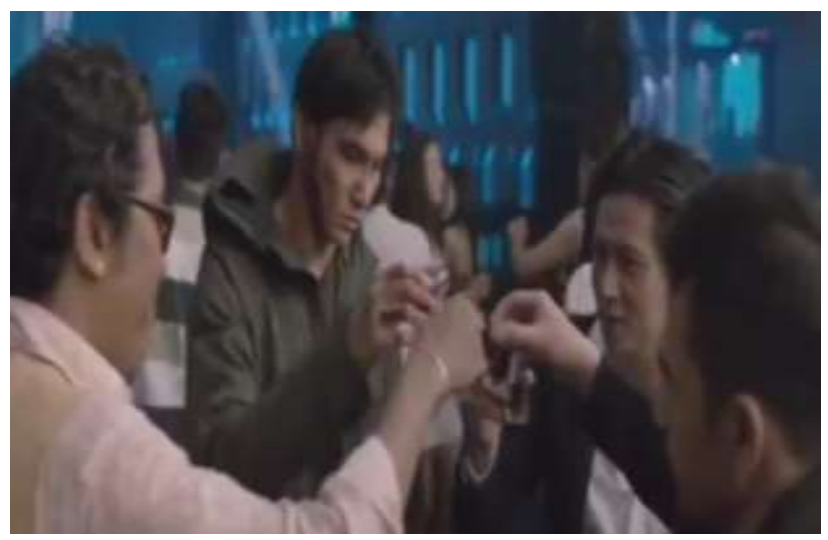

Gambar 5. Ronggur bergabung dengan Kelompok Mafia Narkoba

Gambaran Climax tersebut juga terlihat pada kutipan naskah yang diucapkan oleh Ronggur kepada Tomi sahabatnya, sebagai berikut:

\section{INT.RUMAH.MALAM}

RONGGUR

Gue nggak tau lagi gimana bisa dapetin duit banyak,

Gue nggak mau jadi pecundang!

Gue ingin dianggap sama orang-orang!

Gue pengen orang-orang hargai gue..

Dari kutipan dialog tersebut Ronggur tidak memiliki pilihan lain untuk mendapatkan uang banyak dan ingin dihargai oleh orang lain. Dalam hal ini dimaksudkan kepada orang tua Andini yang tidak menghargai dirinya karena berasal dari kelas sosial yang berbeda. Ekspresi Ronggur yang tertekan juga dipengaruhi dari Ayahnya yang selalu menyudutkan Ronggur karena pengangguran dan tidak memiliki masa depan.z

\section{Resolution}

Pada tahapan ini para tokoh di pertemukan dengan semua masalah-masalah yang terjadi pada para tokoh dengan tujuan untuk mendapatkan solusi atau pemecahan masalah tersebut. Pada tahap ini biasanya para tokoh mulai menemukan titik temu permasalahan yang dihadapi. Tokoh-tokoh juga mulai mencari solusi dari permasalahan yang dihadapi, dalam hal ini adalah Ronggur yang telah menyadari kesalahannya dan berusaha untuk keluar dari mafia narkoba tersebut dengan cara membunuh para mafia narkoba yang telah 
menjebaknya dengan harapan permasalahan akan selesai. Peristiwa tersebut terlihat pada scene 85 pada gambar sebagai berikut:

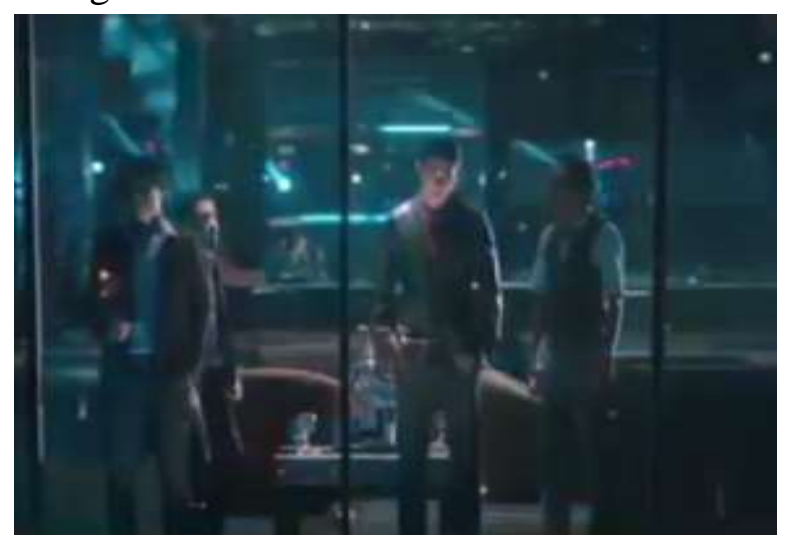

Gambar 6. Ronggur Membunuh Mafia-Mafia Narkoba

Gambar 5 bercerita tentang Ronggur yang menjumpai para mafia Narkoba dan membunuh mereka. Pada scene 85 tersebut menggambarkan Resolution dari tokoh Ronggur yang tidak memiliki solusi lain untuk permasalahannya. Ronggur menganggap permasalahan tersebut telah selesai, namun permasalahannya semakin besar dan rumit. Ronggur justru menjadi buronan polisi yang telah mengetahui perbuatannya. Ronggung kembali ke kampung halamannya di Toba Sumatera Utara. Ronggur meminta bantuan Togar sahabatnya untuk memberikan tempat persembunyian. Sersan Mayor Tebe yang mengetahui permasalahan yang dihadapi Ronggur, mencoba mencari solusi untuk putra sulungnya dengan cara menjumpai Ronggur ditempat persembunyiannya.

\section{Conclusion}

Tahap conclusion merupakan tahap akhir (penyelesaian) dari jalinan struktur dramatik, para tokoh akan mendapat kepastian apakah sad ending atau happy ending atau dapat juga berupa pesan-pesan moral dari peristiwa-peristiwa yang terjadi. Tahap penyelesaian ini bermula pada saat ayah Ronggur yaitu Sersan Mayor Tebe menemui Ronggur di tempat persembunyiannya. Sersan Mayor Tebe memberikan pengertian-pengertian terhadap Ronggur bahwa jalan yang dipilih adalah jalan yang salah. Terjadi perdebatan pada saat Sersan Mayor Tebe memberikan nasehat dan solusi terhadap Ronggur, namun akhirnya Ronggur menyadari kesalahannya dan meminta bantuan terhadap ayahnya. Ronggur pun menyerahkan diri ke Polisi sesuai dengan nasehat ayahnya. Namun, takdir berkata lain, Ronggur meninggal di tembak teman-teman mafianya ketika hendak menyerahkan diri ke polisi. Hal ini dapat dilihat pada scene 94 sebagai berikut:

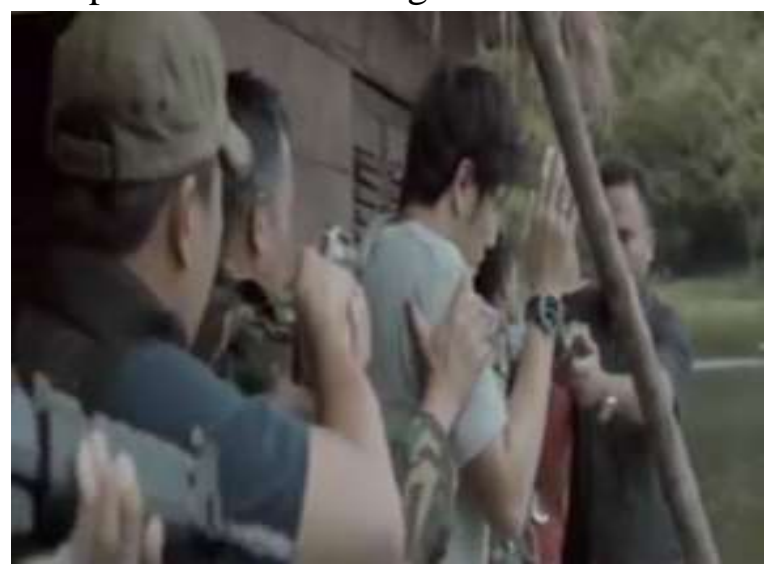

Gambar 7. Ronggur Menyerahkan Diri dengan Polisi 
Plot/Alur menjadi bagian dari struktur dramatik, yang dapat diartikan sebagai rangkaian peristiwa antara satu dengan yang lainnya kemudian dihubungkan dengan hukum sebab akibat. Toba dreams menggunakan simple plot dalam ceritanya, hal ini terlihat dari konflik yang terdapat dalam cerita yang bergerak dari awal hingga akhir dan membentuk menjadi kesatuan cerita. Konflik tersebut bermula dari Ronggur yang menentang keinginan ayahnya dan mencari jalan hidupnya sendiri dengan melarikan diri ke Jakarta. Kemudian Ronggur mendapatkan permasalahan kembali karena tidak direstuinya hubungannya dengan Andini. Konflik yang sangat kompleks juga terjadi pada saat Ronggur bergabung dengan mafia-mafia Narkoba.

\section{PENUTUP}

Struktur dramatik dari film Toba Dreams Karya Benny Setiawan terdiri dari tahap pengenalan tokoh Sersan Mayor Tebe dan Ronggur. Penanjakan aksi terlihat pada saat Sersan Mayor Tebe telah pensiun dari pekerjaannya memilih ingin pulang ke kampung halaman dan ingin membawa serta keluarganya. Namun, Ronggur putra sulung Sersan Mayor Tebe menentang keinginan ayahnya untuk pindah kekampung halaman ayahnya di Toba. Kerumitan terjadi terhadap hubungan Sersan Mayor Tebe dan Ronggur yang samasama memiliki sifat yang keras. Ronggur yang ikut ayahnya pindah ke kampung merasa tidak senang dan melarikan diri ke kota Jakarta untuk bertemu dengan kekasihnya Andini sekaligus mencari pekerjaan.

Tahapan Crisis terjadi pada saat Ronggur merasa prustasi dengan masalah yang dihadapinya. Film Toba Dreams menguraikan permasalahan melalui tokoh Ronggur yang telah terjebak dengan perumitan masalah yang besar. Mulai dari permasalahannya dengan Sersan Mayor Tebe yaitu ayahnya, permasalahannya dengan keluarga Andini yang melarangnya untuk tidak berhubungan dengan Andini hingga terjebaknya Ronggur dengan mafia-mafia narkoba. Climax terjadi saat Ronggur yang tidak memiliki pilihan bergabung dengan mafia-mafia narkoba dan bekerja sebagai pengedar.

Pencarian solusi terjadi saat Ronggur menerima persyaratan yang diberikan oleh bos mafia narkoba agar dirinya terlepas dari genggaman mafia tersebut. Tetapi Ronggur justru terperangkap oleh rencana yang diberikan teman-teman mafia nya. Disisi lain, Sersan Mayor Tebe yang mengetahui permasalahan yang dihadapi Ronggur, mencoba mencari solusi untuk putra sulungnya dengan cara menjumpai Ronggur. Tahapan akhir dalam cerita film Toba Dreams, Ronggur menyerahkan diri kepada Polisi ditemani oleh ayahnya. Namun, mafia-mafia narkoba tersebut ternyata mengintainya dan menembaknya. Dalam film Toba Dreams terdapat makna keberagaman umat beragama. Hal itu terlihat pada saat Ronggur menikahi Andini yang beragama Islam.

\section{DAFTAR PUSTAKA}

[1] Harymawan, RMA. 1988. Dramaturgi. Bandung: CV Rosda.

[2] Moleong, Lexy J. 2002. Metodologi Penelitian Kualitatif. Bandung: PT Remaja Rosdakarya

[3] Pratista, Himawan. 2008. Memahami Film. Yogyakarta: Homerian Pustaka.

[4] Peransi, D.A. 2005. Film/Media/Seni. Jakarta: FFTV-IKJ Press. 
[5] Saptaria, Rikrik El. 2005. Acting Handbook, Panduan Praktis Akting untuk Film dan Teater. Bandung: Rekayasa Sains. 